\title{
组织型纤溶酶原激活因子及其抑制因子的信使 核糖核酸在大鼠睪丸中的定位*
}

\author{
周红明 刘以训**

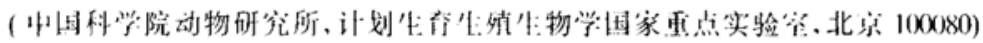

\section{关键词纤溶酶原激活因子 纤溶酶原激活因子抑制因子 精子发生 原位杂交}

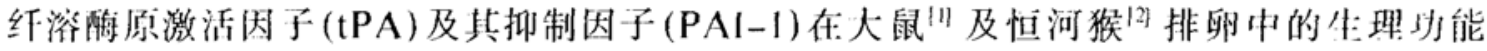
ᄂ得到证实. 为研究 $\mathrm{tPA} / \mathrm{PAI}-1$ 系统在精子发生过程中的作用, 我们用原位杂交方法观察了 $\therefore$ 者的份使核糖核酸 (mRNA) 在成年及㭃年大鼠睪炕曲细精管中的定位. 结果证实: (1) 住㭃 隹大鼠裂丸中 tPA 只在某些曲细精管中表达, 表达部位在支持细胞和初级精母细胞, PAI-1 在: 间质及大部分曲细精管的初级精提细胞中都有哀达; (2) 在成年大鼠睪丸中 tPA 只在支持细 胞中表达, 表达水将随生精周期波动; PAI-1 在间质细胞, 管周细胞及各分化阶段的生: 精细 胞中都们表达. tPA/PAI-1 系统在曲细精管中的表达表明, 该系统可能在精子发生过程中起

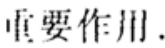

\section{1 材料和方法}

\section{1 实验动物及主要试剂}

成年 (4月龄) 及幼年 (20 日龄) SD 大鼠由中国科学院动物研究所饲养场供应。大鼠 tPA 及 PAI-1 cDNA 质粒由瑞典 Umeå 大学 Ny 教授提供, RNA 标记试剂盒 (DIG RNA Labeling Kit) 及检测试剂 (Anti-digoxigenin-AP Fab Fragment, Blocking Reagent, NBT, BCIP) 购自 Boehringer Mannheim( 北京), RNA 聚合酶 T7 和 SP6 购自 Promega( 北宗)。限 制州:内切酶 HindIII, PvuII, 多聚赖氮酸购自华美公司 (北京).

\subsection{Dig-cRNA 探针制备}

tPA 和 PAI-1 cDNA 质粒经 HindIII 酶切线性化后, 用 RNA 标记试剂盒经 RNA聚合㱙 T7 转录反义 cRNA; 经 PvulI 线性化后, 用 SP6 转录正义 cRNA.

\section{3 原位杂交及检测}

新鲜大鼠睪好经液氮速冻后, 平衡至 $-20^{\circ} \mathrm{C}$ 作常规冰冻切片 $(20 \mu \mathrm{m})$. 将切片贴附在铺们

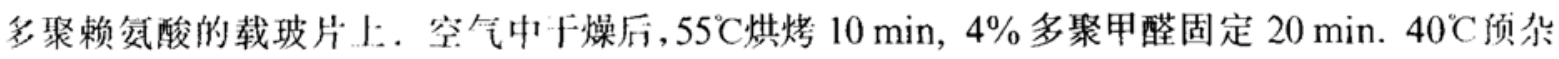
父 $2 \mathrm{~h}$, 加稀释好的 dig- 标记的正义或反义 cRNA 探针, $45^{\circ} \mathrm{C}$ 反应 $20 \mathrm{~h}$. 探针检测按试剂盒 说明, 用明视野显微摄影记录, 照片上黑色为阳性反应指示.

1995-04-22 收樆, 1995-(99-06 收修改棡

* 门然科学基金和国家计划生㐬委员会基金资助项目

**联系人 


\section{2 结果和讨论}

\section{1 tPA mRNA 在大鼠睪丸中的定位}

在成年大鼠睪丸中, tPA mRNA 主要定位于支持细胞, 间质细胞中无 tPA mRNA 表达 (图 1(a)). 在低倍视野下, tPA mRNA 含量在不同生精阶段的曲细精管明显不同 (图 1(b)). 在幼年大鼠睪丸中 tPA mRNA 主要定位于支持细胞和初级精母细胞(图 2(a)); 在低倍视 野下显示不同曲细精管间 tPA 表达有很大差异 (图 2(b)).
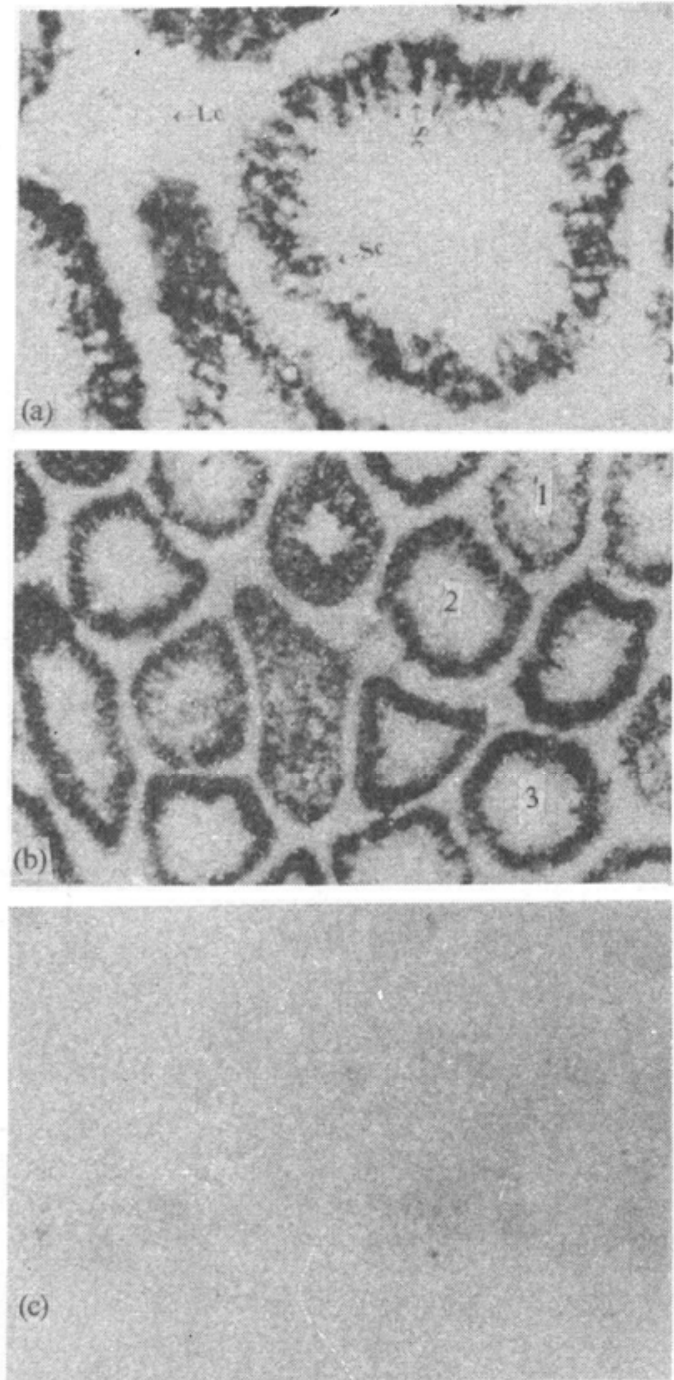

图 1 tPA mRNA 在成年大鼠睪丸中的定位 (a)为高倍 $(100 \times)$ 视野, 显示 tPA mRNA 特异定位于支持细 胞 (Sc), 间质 Leydig 细胞 (Lc) 为表达阴性; (b) 为低倍 $(40 \times)$ 视野, 显示 tPA 表达在不同曲细精管支持细胞中有 明显的差异, 曲细精管 1，2，3 处于不同生精周期, 染色深 浅有明显差异, 反映不同 tPA mRNA 表达水平; (c) 为正 义tPA cRNA 对照, 不显示阳性染色
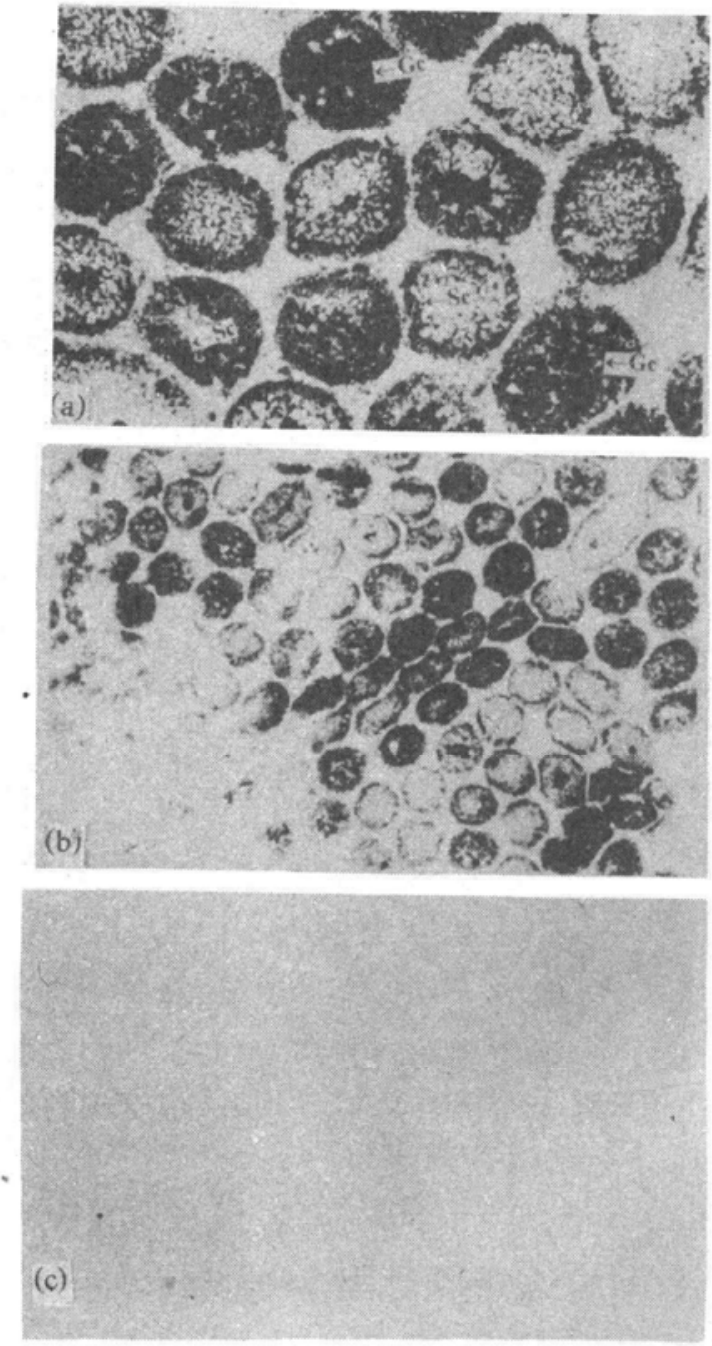

图 $2 \mathrm{tPA}$ mRNA 在幼年大鼠睪丸中的定位 (a)为高倍 $(100 \times)$ 视野,显示 tPA mRNA 特异定位于支持细 胞 $(\mathrm{Sc})$ 及生精细胞 $(\mathrm{Gc})$; (b) 为低倍 $(40 \times)$ 视野, 显示 tPA mRNA 在不同曲细精管中表达的差异; ( c) 为正义 tPA cRNA 对照, 不显示阳性染色 


\subsection{PAI-1 mRNA 在大鼠睪丸中的定位}

成年大鼠间质细胞, 管周细胞及各分化阶段的生精细胞均表达 PAI-1 mRNA(图 3(a)), PAI-1 在成年大鼠各曲细精管中的表达无明显差异 (图 3(b)).

在幼年大鼠曲细精管中 PAI-1 mRNA 主要定位于初级精母细胞 (图 4(a)). 低倍下有些 曲细精管断面检测不到 PAI-1 mRNA 的存在 (图 4(b)), 说明 PAI-1 的表达可能与曲细精管 的分化有关.
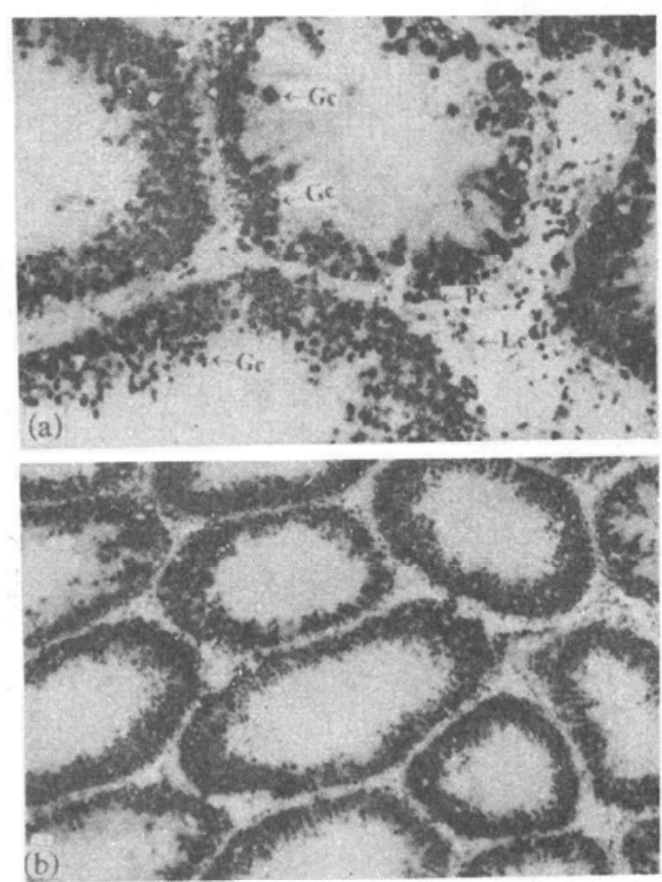

(c)

图 3 PAI-1 mRNA 在成年大鼠睪丸中的定位 (a) 为高倍 $(100 \times)$ 视野, 显示 PAI- 1 在间质 Leydig 细胞 (Lc), 管周细胞 $(\mathrm{Pc})$ 及各分化期的生精细胞 (Gc) 都 有表达; (b) 为低倍 $(40 \times)$ 视野,显示 PAI-1 在不同曲细 精管中表达无明显差异; (c) 为正义 PAI-1 cRNA 对 照, 无染色阳性
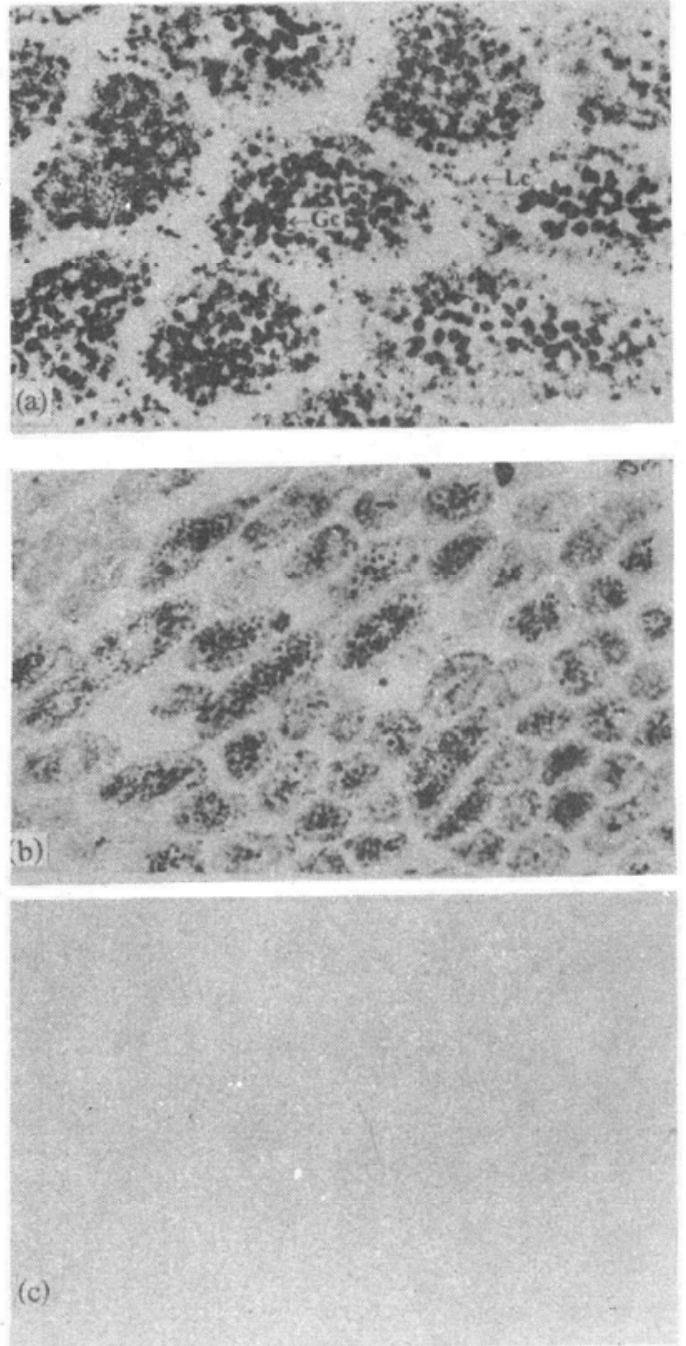

图 4 PAI-1 mRNA 在幼年大鼠罳丸中的定位 (a) 为高倍 $(100 \times)$ 视野, 显示 PAI-1 主要在间质 Leydig 细胞 (Lc) 及初级精母细胞 $(\mathrm{Gc})$ 中表达; (b) 为低倍 $(40 \times)$ 视野,显 示部分曲细精管为表达阴性; (c) 为正义 PAI-1 cRNA 对照

精子发生过程是支持细胞上皮被局部破坏和修复的过程, 蛋白水解酶的精细调节在此过 程中有重要意义. 由于纤溶酶具有广泛的细胞外蛋白水解酶活性, 其前体受纤溶酶原激活因 
5 (PA) 激活, 所以 PA 及其抑制因子 (PAI) 的表达对曲细精管内的蛋白水解系统可能有重要 作用。对大鼠利小鼠曲细精管分段培养研究表明, tPA 与精子发生有密切关系 ${ }^{32}$ ? . Vihko 等比 较不同期旧细精管 tPA mRNA 含量, 证实在生精活动最活跃的第 VII, VIII 两期 tPA mRNA

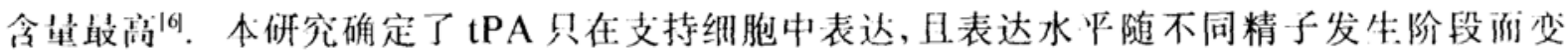
化, 提示支持细胞 tPA 表达与精子发生密切相关。有报道管周细胞是睪丸内 PAI-I 活性: 的 来源”, 主: 要维持基底膜的稳定。但由于支持细胞间存在紧密连接, 管周细胞表迟的 PAI-1 不叮能进人曲细精管调节PA 活性, 曲细精管内可能存在PAI-1 表达系统. 本研究除肯定了 成年大鼠管周细胞表达 PAI-1 外, 还首次观察到 PAI-1 在不同分化期生:精细胞中表达。这问 免疾定位的观察吻合 ${ }^{[8]}$. 从个体发生看, 睪丸与卵巢同源, 受相同促性腺激素调节, 并表达相 同的基因，有趣的是卵子表达 $\mathrm{TPA}^{[9,10]}$, 而不表达 PAI-1; 与此相反, 生精细胞表达 PAI-1, 而 不表达 tPA, 其生理意义有待进一步研究。

\section{参考文献}

I Liu Yixun. Peng Xiaorong, Ny Tor. Tissue-specific and time-coordinated hormone regulation of plasminogen activator inhibitor type-1 and tissue-type plasminogen activator in the rat ovary during gonadotropin-induced ovulation. Eur $J$ Biochem, 1991, 195: $549 \sim 555$

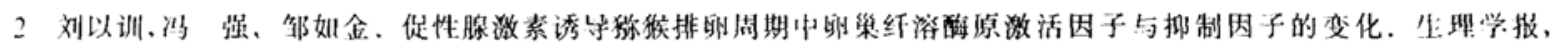
1991, 43: $472 \sim 479$

3 Lacroix M, Parvinen M, Fritz. I B. Localization of testicular plasminogen activator in discrete portion (stages VII and VIII) of the seminiferous tubules. Biology of Reproduction, 1981. 25: 143 146

4 Vihko K K. Suominen J O, Parvinen M. Cellular regulation of plasminogen activator secretion during spermatogenesis. Biology of Reproduction, 1984, 31: $383 \sim 389$

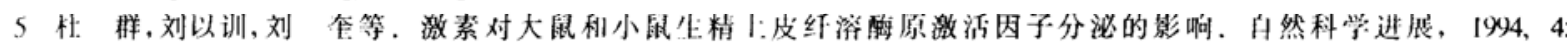
$983 \sim 987$

6 Vihko K K. Pentila T L, Parvinen M et al. Regulation of urokinase- and tissue-type plasminogen activator gene expression in the rat seminiferous epithelium. Molecular Fndocrinology, 1989, 3:52 59

7 Nargolwalla C. MoCabe D, Fritz I B. Modulation of messenger RNA for tissue-type plasminogen activator in rat Sertoli cells. and levels of messenger RNA for plasminogen activator inhibitor in testis peritubular cells. Molecular and Cellular Fndocrinology, 1990, 70: $73 \sim 80$

8 Liu Yixun, Liu Kui, Zhou Hongming of al. Hormonal regulation of tissue-type plasminogen activator and plasminogen activator inhibitor type-1 in cultured monkey Sertoli cells. Human Reproduction, 1995, 10: $719 \sim 727$

9) Liu Yixun, Ny Tor, Sarkar D et al. Identification and regulation of tissue-type plasminogen activator activity in rat cumulus-nocyte complex. Fndocrinology, 1986, 119:1578 1587

10 liu Yixun. Hsuch A J W. Plasminogen activator activity in cumulus-oocyte complexes of gonadotropin-treated rats during periovulatory periods. Biology of Reproduction, 1987, 36: 1055 1062 